\title{
A Re-examination of the Reaction of Dichloro-tris- (triphenylphosphino)ruthenium(II) with Benzonitrile: Crystal structures of triphenylphosphine chloro ruthenium complexes
}

\author{
Santina S. Cruz, Donna S. Amenta, John W. Gilje* \\ Department of Chemistry and Biochemistry, MSC 4501, James Madison University, Harrisonburg, VA \\ 22807, USA \\ Glenn P.A. Yap* \\ Department of Chemistry and Biochemistry, University of Delaware, Newark, DE 19716, USA
}


* Corresponding authors. e-mail addresses: amentads@jmu.edu (D.S. Amenta), giljejw@jmu.edu (J.W. Gilje), gpyap@UDel.Edu (G. P. A. Yap). 
The reaction of $\mathrm{RuCl}_{2}\left(\mathrm{PPh}_{3}\right)_{3}$ with benzonitrile has been investigated in toluene. When excess benzonitrile is employed cis- $\mathrm{RuCl}_{2}\left(\mathrm{PPh}_{3}\right)_{2}(\mathrm{NCPh})_{2}$ is obtained and has been characterized by $\mathrm{X}$ ray diffraction. This contrasts to acetonitrile which yields trans- $\mathrm{RuCl}_{2}\left(\mathrm{PPh}_{3}\right)_{2}(\mathrm{NCMe})_{2}$. With excess $\mathrm{RuCl}_{2}\left(\mathrm{PPh}_{3}\right)_{3}$ a triply chloro bridged diruthenium compound $\left(\mathrm{PPh}_{3}\right)_{2}(\mathrm{Cl}) \mathrm{Ru}(\mu$ $\mathrm{Cl})_{3} \mathrm{Ru}(\mathrm{NCPh})\left(\mathrm{PPh}_{3}\right)_{2}$ is obtained. A dark red crystalline side product, formed during the preparation of $\mathrm{RuCl}_{2}\left(\mathrm{PPh}_{3}\right)_{3}$, is identified as $\left[\mathrm{Ph}_{3} \mathrm{PMe}\right]\left[\mathrm{RuCl}_{4}\left(\mathrm{PPh}_{3}\right)_{2}\right]$ by low temperature crystal structure determination with better precision than previously reported. In each case, the Ru atom presents octahedral coordination geometry.

Keywords: Ruthenium, triphenylphosphine, benzonitrile, crystal structure, IR spectra 


\section{Introduction}

The hydrolysis of nitriles produces amides and carboxylic acids [1, 2]. Such reactions are of considerable synthetic significance and efficient catalysts can be found among the complexes of the platinum block metals [1]. In these processes the catalytic metal center coordinates one or several nitriles and facilitates subsequent hydrolysis, the details of which depend on the stereochemistry of the nitrile complex. Thus, cis-dinitrile complexes often undergo hydrolytic nitrile coupling, which cannot occur in trans-complexes [1]. There a number of examples of group 8 halide complexes that catalyze these reactions [1] and we are interested in establishing bis nitrile halide complexes with various nitrile stereochemistries.

In fact, six-coordinate bis-phosphorus-, bis-nitrogen donor complexes of group 8 metal dihalides are frequently encountered with tethered ligands that clearly influence if cis or trans coordination is accessible. Indeed out of 214 structures reported in the Cambridge Crystallographic Data Base (CCDB), only eight structures have monodentate ligands exclusively [3]. Out of these eight compounds, six involve pyrazoles as N-donor ligands [3]. Only two nitrile structures, one cis [4] and one trans [5] have been reported, both with acetonitrile and both with chlorides and both on ruthenium.

In 1969 Wilkinson reported that $\mathrm{RuCl}_{2}\left(\mathrm{PPh}_{3}\right)_{2}(\mathrm{NCR})_{2}$ can be obtained from the reactions of $\mathrm{RuCl}_{2}\left(\mathrm{PPh}_{3}\right)_{3}$ with excess nitrile carried out in acetone [6]. In his paper, 14 nitriles were investigated and the products characterized by IR spectroscopy and chemical analysis. In all cases two bands in the $\mathrm{CN}$ stretching region were observed. While the stereochemistry of all of these was not individually discussed, both the acetonitrile and acrylonitrile complexes were assigned as cis- $\mathrm{RuCl}_{2}\left(\mathrm{PPh}_{3}\right)_{2}(\mathrm{NCR})_{2}$. It is reasonable to postulate that the remaining examples also have cis structures. However, when corresponding reactions of acetonitrile and acrylonitrile are carried out in toluene the products show only a single $\mathrm{CN}$ stretching vibration. Wilkinson concluded that trans- $\mathrm{RuCl}_{2}\left(\mathrm{PPh}_{3}\right)_{2}(\mathrm{NCR})_{2}$ is formed in these reactions. More recently cis$\mathrm{RuCl}_{2}\left(\mathrm{PPh}_{3}\right)_{2}(\mathrm{NCMe})_{2}$ was obtained and structurally characterized from the reaction carried out in ethanol followed by crystallization from acetonitrile [4]. While there are no X-ray structures of trans- $\mathrm{RuCl}_{2}\left(\mathrm{PPh}_{3}\right)_{2}(\mathrm{NCR})_{2}$, there are several closely related complexes that have been 
structurally characterized. The $\operatorname{PPr}_{3}^{\mathrm{i}}$ and $\mathrm{P}(\mathrm{OMe})_{2} \mathrm{Ph}$ analogs were isolated from the reactions of $\left[\mathrm{RuCl}_{2}(p \text {-cymene })\right]_{2}$ with $\operatorname{PPr}_{3}^{\mathrm{i}}$ and $\mathrm{MeCN}$ in toluene[5] and $\left[\mathrm{RuCl}_{2}(\mathrm{COD})_{2}(\mathrm{NCMe})_{2}\right]_{2}$ and $\mathrm{P}(\mathrm{OMe})_{2} \mathrm{Ph}$ in $\mathrm{MeCN}$ [7], respectively. Based on these reports, it seemed possible that trans$\mathrm{RuCl}_{2}\left(\mathrm{PPh}_{3}\right)_{2}(\mathrm{NCR})_{2}$ might be accessed from reactions carried out in toluene. In related chemistry, the reaction of excess $\mathrm{RuCl}_{2}\left(\mathrm{PPh}_{3}\right)_{3}$ with nitriles has not been reported. However, crystals of $(\mathrm{L})_{2}(\mathrm{Cl}) \mathrm{Ru}(\mu-\mathrm{Cl})_{3} \mathrm{Ru}(\mathrm{NCMe})(\mathrm{L})_{2}$ ( $\mathrm{L}=$ Diphenyl-2-indolylphosphine) were isolated during attempted recrystallization of $\mathrm{RuCl}_{2}(\mathrm{~L})_{3}$ from acetonitrile. While the structure was reported, no further characterization has appeared [8].

Because of the paucity of examples of bis monodentate nitrile, bis monodentate phosphine ruthenium (indeed any group 8 metal) dihalide complexes, especially those with trans ligands, we decided to revisit the chemistry of dichloro-tris-(triphenylphosphino)ruthenium(II) with a different nitrile, benzonitrile.

\section{Experimental Section}

2.1. General Procedure. All manipulations were conducted under inert $\mathrm{N}_{2}$ or argon atmospheres using standard Schlenk line and glove box techniques. Solvents were dried using an Innovative Technology, Inc. solvent purification system. $\mathrm{RuCl}_{2}\left(\mathrm{PPh}_{3}\right)_{3}$ was synthesized using the published procedure [9]. NMR spectra were obtained using a Bruker Avance DRX-400 NMR and Bruker Avance DRX-300 NMR with all chemical shifts reported in ppm. IR spectra were obtained by KBr pellets using a ThermoNicolet Avatar 370 FT-IR between $4000 \mathrm{~cm}^{-1}$ and $400 \mathrm{~cm}^{-1}$. Melting

points were obtained using a Mel-Temp Electro-thermal apparatus with all samples being prepared in the glove box. Elemental Analysis was performed by Galbraith Laboratories, Knoxville, TN.

2.2. Synthesis of cis-RuCl $2\left(\mathrm{PPh}_{3}\right)_{2}(\mathrm{NCPh})_{2}$ : Wilkinson prepared cis- $\mathrm{RuCl}_{2}\left(\mathrm{PPh}_{3}\right)_{2}(\mathrm{NCPh})_{2}$ by the reaction of $\mathrm{RuCl}_{2}\left(\mathrm{PPh}_{3}\right)_{3}$ with $\mathrm{NCPh}$ in acetone and characterized it by elemental analysis and infrared spectroscopy [1]. In our hands this compound can also be obtained by the reaction in toluene. A $0.099 \mathrm{~g}(0.10 \mathrm{mmol})$ sample of $\mathrm{RuCl}_{2}\left(\mathrm{PPh}_{3}\right)_{3}$ was added to $0.032 \mathrm{~mL}(0.033 \mathrm{~g}, 0.32$ $\mathrm{mmol}$ ) of NCPh in $2 \mathrm{~mL}$ toluene. The resulting mixture was stirred rapidly for several seconds and immediately filtered. After 3-6 hours at room temperature yellow crystals began to form. 
After about 24 hours the supernatant was removed and the yellow crystalline $\mathrm{RuCl}_{2}\left(\mathrm{PPh}_{3}\right)_{2}(\mathrm{NCPh})_{2}$ was dried under vacuum to yield $0.093 \mathrm{~g}(0.10 \mathrm{mmol}, 100 \%)$ of $\mathrm{RuCl}_{2}\left(\mathrm{PPh}_{3}\right)_{2}\left(\mathrm{C}_{7} \mathrm{H}_{5} \mathrm{~N}\right)_{2}$, m.p. $=186.5-187.9^{\circ} \mathrm{C}(\mathrm{dec}), \operatorname{IR}\left(\mathrm{KBr}\left(\mathrm{cm}^{-1}\right): 3052 \mathrm{~m}, 2240 \mathrm{~m}, 2230 \mathrm{~m}\right.$, $2216 \mathrm{~m}, 1431 \mathrm{~s}, 1259 \mathrm{w}, 1085 \mathrm{~m}, 1023 \mathrm{w}, 740 \mathrm{~s}, 692 \mathrm{~s}, 512 .{ }^{31} \mathrm{P} \mathrm{NMR}\left(\mathrm{CDCl}_{3}\right): 25.6 \mathrm{~s}$. $\mathrm{X}$-ray quality crystals were obtained from a similar reaction that took place in an NMR tube in dtoluene

2.3. Synthesis of $\mathrm{Ru}_{2} \mathrm{Cl}_{4}\left(\mathrm{PPh}_{3}\right)_{4}(\mathrm{NCPh})$ (1): A $15 \mathrm{~mL}$ sample of acetone was added to a $25 \mathrm{~mL}$ round bottom flask containing a $0.500 \mathrm{~g}(0.522 \mathrm{mmol})$ sample of $\mathrm{RuCl}_{2}\left(\mathrm{PPh}_{3}\right)_{3}$. The solution was allowed to stir for approximately 5 minutes forming a slurry of $\mathrm{RuCl}_{2}\left(\mathrm{PPh}_{3}\right)_{3}$. A $17.9 \mu \mathrm{L}(0.174$ mmol) sample of $\mathrm{NCPh}$ was added and a red-orange solution resulted. After approximately 72 hours, dark red X-ray quality crystals formed from a transparent burnt orange solution. The supernatant was decanted and the precipitate was dried under vacuum to yield $0.264 \mathrm{~g}(0.163$ mmol, $62.7 \%$ yield) of a dark red-brown crystalline $\mathrm{Ru}_{2} \mathrm{Cl}_{4}\left(\mathrm{PPh}_{3}\right)_{4}(\mathrm{NCPh})$. The compound analyzed as the diacetone solvate as observed in the crystal structure. Elem. Anal. Calcd for $\mathrm{C}_{85} \mathrm{H}_{77} \mathrm{Cl}_{4} \mathrm{NO}_{2} \mathrm{P}_{4} \mathrm{Ru}\left(\mathrm{M}_{\mathrm{r}}=1,612.40\right): \mathrm{C} 63.31 \% ; \mathrm{H} 4.81 \%$; $\mathrm{N} \mathrm{0.87 \%}$. Found: $\mathrm{C} 62.47 \% ; \mathrm{H}$ 4.79\%; N 0.95\%. IR (KBr, cm $\left.{ }^{-1}\right): 3050$ m, 2226 m, 1479 m, 1432 s, 1087 m, 741 m, 691 s, 536 s, 520 s. The ${ }^{31} \mathrm{P}$ NMR $\left(\mathrm{CDCl}_{3}\right.$, ambient) spectrum is second order and can be simulated [10] using the following parameters: $\mathrm{P}_{\mathrm{A}} 45.59 \mathrm{ppm}, \mathrm{P}_{\mathrm{B}} 46.21 \mathrm{ppm}, \mathrm{P}_{\mathrm{C}} 47.31, \mathrm{P}_{\mathrm{D}} 49.96 ; \mathrm{J}_{\mathrm{AB}}=29.6 \mathrm{~Hz}$, $\mathrm{J}_{\mathrm{AC}}=2.1 \mathrm{~Hz}, \mathrm{~J}_{\mathrm{AD}}=2.2 \mathrm{~Hz}, \mathrm{~J}_{\mathrm{BD}}=2.5 \mathrm{~Hz}, \mathrm{~J}_{\mathrm{CD}}=37.2 \mathrm{~Hz}$.

2.4. X-ray Crystal Structure Determinations. Crystal data, refinement details and selected bond metrics are presented in Tables 1-4. The data crystals were selected and mounted on plastic mesh using Paratone oil flash-cooled to the data collection temperature. Data were collected on a Bruker-AXS APEX II Duo CCD diffractometer with graphite-monochromated Mo-Ka radiation $(\lambda=0.71073 \AA)$. Unit cell parameters were obtained from 60 data frames, $0.3^{\circ} \omega$, from three different sections of the Ewald sphere, and refined with the entire diffraction data set. The systematic absences in the data and the unit cell parameters were uniquely consistent to the reported space groups for $\mathrm{Ru}_{2} \mathrm{Cl}_{4}\left(\mathrm{PPh}_{3}\right)_{4}(\mathrm{NCPh})$ and $\left[\mathrm{CH}_{3} \mathrm{PPh}_{3}\right]\left[\mathrm{RuCl}_{4}\left(\mathrm{PPh}_{3}\right)_{2}\right]$. No symmetry higher than triclinic was observed for $\mathrm{RuCl}_{2}\left(\mathrm{PPh}_{3}\right)_{2}(\mathrm{NCPh})_{2}$ and solution in the centrosymmetric option yielded chemically reasonable and computationally stable results of refinement. The data 
sets were treated with absorption corrections based on redundant multiscan data [11]. The structure was solved using direct methods and refined with full matrix, least-squares procedures on $\mathrm{F}^{2}$ [12]. The absolute structure parameter for $\left[\mathrm{CH}_{3} \mathrm{PPh}_{3}\right]\left[\mathrm{RuCl}_{4}\left(\mathrm{PPh}_{3}\right)_{2}\right]$ refined to nil indicating the true hand of the data had been determined. Two molecules of toluene solvent were found cocrystallized disordered in the asymmetric unit with $\mathrm{RuCl}_{2}\left(\mathrm{PPh}_{3}\right)_{2}(\mathrm{NCPh})_{2}$ having each toluene molecule modeled in two positions, treated with equal anisotropic atomic displacment parameters for chemically equivalent atoms and constrained idealized geometry with refined site occupancy ratios of 64/36 and 54/46. Two molecules of acetone solvent were found cocrystallized in the asymmetric unit with $\mathrm{Ru}_{2} \mathrm{Cl}_{4}\left(\mathrm{PPh}_{3}\right)_{4}(\mathrm{NCPh})$ and were treated as idealized rigid groups[13] having anisotropic, three-dimensional rigid bond constraints. All non-hydrogen atoms were refined with anisotropic displacement parameters. All hydrogen atoms were treated as idealized contributions. Scattering factors and anomalous dispersion coefficients are contained in the SHELXTL program library [12]. Molecular graphics were obtained using Mercury CSD [14]. The crystallographic information files have been deposited as CCDC 1413994-1413996. These data can be obtained free of charge via www.ccdc.cam.ac.uk/conts/retrieving.html (or from the CCDC, 12 Union Road, Cambridge CB2 1EZ, UK; fax: +44 1223 336033; email: deposit@,ccdc.cam.ac.uk).

\section{Results and Discussion}

\subsection{The Reaction of $\mathrm{RuCl}_{2}\left(\mathrm{PPh}_{3}\right)_{3}$ with excess $\mathrm{NCPh}$}

Based on Wilkinson's observation that the reactions with excess of $\mathrm{NCMe}$ or $\mathrm{NCCH}=\mathrm{CH}_{2}$ with $\mathrm{RuCl}_{2}\left(\mathrm{PPh}_{3}\right)_{3}$ in toluene lead to trans- $\mathrm{RuCl}_{2}\left(\mathrm{PPh}_{3}\right)_{2}(\mathrm{NCR})_{2}$ [6], we anticipated that a corresponding trans isomer would form with $\mathrm{NCPh}$. However, the reaction of $\mathrm{RuCl}_{2}\left(\mathrm{PPh}_{3}\right)_{3}$ with approximately 3 equivalents of $\mathrm{NCPh}$ in toluene exclusively yields cis$\mathrm{RuCl}_{2}\left(\mathrm{PPh}_{3}\right)_{2}(\mathrm{NCPh})_{2}$, in good yield, displaying the characteristic IR spectrum with two medium peaks at bands in the $\mathrm{C} \equiv \mathrm{N}$ stretching region consistent with a cis nitrile as confirmed by an X-ray crystal structure. We attempted the reaction a number of times and always obtained the cis isomer. In fact, we obtained no evidence for the trans complex in solution as NMR spectra obtained immediately after mixing the reagents was the same as that obtained on crystalline cis$\mathrm{RuCl}_{2}\left(\mathrm{PPh}_{3}\right)_{2}(\mathrm{NCPh})_{2} \mathrm{We}$ also have seen no indication of the cis isomer isomerizing to trans as the $\mathrm{nmr}$ spectra of samples in sealed $\mathrm{nmr}$ tubes remain unchanged over several weeks 
$\mathrm{Cl}_{2} \mathrm{Ru}\left(\mathrm{PPh}_{3}\right)_{3}+2 \mathrm{PhCN} \longrightarrow$

The structure of cis- $\mathrm{RuCl}_{2}\left(\mathrm{PPh}_{3}\right)_{2}(\mathrm{NCPh})_{2}$ (Fig. 1) shows nearly octahedral coordination about the $\mathrm{Ru}$. The greatest deviations from the idealized $90^{\circ}$ cis bond angles is N-Ru-N, 86.12(12) ${ }^{\circ}$ and $\mathrm{Cl}-\mathrm{Ru}-\mathrm{Cl}, 95.54(4)^{\circ}$. The typical bond distances and metrical parameters around the $\mathrm{Ru}$ atom very closely resemble those in $\mathrm{RuCl}_{2}\left(\mathrm{PPh}_{3}\right)_{2}(\mathrm{NCMe})_{2}$ [24]. The $\mathrm{C} \equiv \mathrm{N}$ distances $(1.143(5)$ and 1.145(5)) are indistinguishable from the mean $\mathrm{C} \equiv \mathrm{N}$ distance of 1.141(31) for the 895 benzonitrile transition metal complexes appearing in the Cambridge Crystallographic Data Base (CCDB) $[15,16]$.

\subsection{The Reaction of excess $\mathrm{RuCl}_{2}\left(\mathrm{PPh}_{3}\right)_{3}$ with $\mathrm{NCPh}$}

Consistent with Wilkinson's report, we were also able to obtain cis- $\mathrm{RuCl}_{2}\left(\mathrm{PPh}_{3}\right)_{2}(\mathrm{NCPh})_{2}$ from reactions of $\mathrm{RuCl}_{2}\left(\mathrm{PPh}_{3}\right)_{3}$ with excess $\mathrm{NCPh}$ carried out in acetone. However, when an excess of $\mathrm{RuCl}_{2}\left(\mathrm{PPh}_{3}\right)_{3}$ is employed a diruthenium complex, $\left(\mathrm{Ph}_{3} \mathrm{P}\right)_{2}(\mathrm{Cl}) \mathrm{Ru}(-\mu-$ $\mathrm{Cl})_{3} \mathrm{Ru}(\mathrm{NCPh})\left(\mathrm{PPh}_{3}\right)_{2}$, is obtained.

$$
2 \mathrm{Cl}_{2} \mathrm{Ru}\left(\mathrm{PPh}_{3}\right)_{3}+\mathrm{PhCN} \longrightarrow
$$

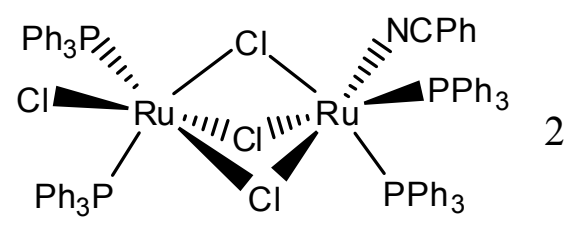

The darkly colored material shows a single IR band in the $\mathrm{C} \equiv \mathrm{N}$ stretching region and exhibits a second order $\mathrm{ABCD}{ }^{31} \mathrm{P}$ spectrum, which indicates four non-equivalent phosphorus 
atoms. The simulated spectrum [10] yields $\mathrm{J}_{\mathrm{PA}-\mathrm{PB}}=29.6 \mathrm{~Hz}$ and $\mathrm{J}_{\mathrm{PC}-\mathrm{PD}}=37.2 \mathrm{~Hz}$. These values are consistent with two sets of two phosphine ligands cis coordinated to octahedral ruthenium centers. The fact that $\mathrm{P}_{\mathrm{A}}$ couples to both $\mathrm{P}_{\mathrm{C}}$ and $\mathrm{P}_{\mathrm{D}}$ with an approximate $2 \mathrm{~Hz}$ coupling constant and $P_{B}$ couples with $P_{D}$ with a similar value indicates that all four phosphorus atoms are in the same molecule. These data are consistent with a diruthenium species and with the crystal structure (Fig. 2) which shows the product to be a mono-benzonitrile adduct $\left(\mathrm{Ph}_{3} \mathrm{P}\right)_{2}(\mathrm{Cl}) \mathrm{Ru}(-\mu-$ $\mathrm{Cl})_{3} \mathrm{Ru}(\mathrm{NCPh})\left(\mathrm{PPh}_{3}\right)_{2}$. Although the CCDB shows 58 examples of compounds containing a $\left(\mathrm{R}_{3} \mathrm{P}\right)_{2} \mathrm{Ru}(-\mu-\mathrm{Cl})_{3} \mathrm{Ru}\left(\mathrm{PR}_{3}\right)_{2}$ trichloro bridged diruthenium unit $[15,16]$ and although nitrile containing trichloro compounds have been proposed based on spectroscopic and chemical analysis when chelating diphosphines are employed [17], this is the first reported structure of a trichloro-bridged phosphine diruthenium nitrile complex that persists in solution.

The geometry of the $\left(\mathrm{Ph}_{3} \mathrm{P}\right)_{2}(\mathrm{Cl}) \mathrm{Ru}(-\mu-\mathrm{Cl})_{3} \mathrm{Ru}(\mathrm{NCPh})\left(\mathrm{PPh}_{3}\right)_{2}$ molecule consists of two distorted octahedral ruthenium centers joined by a triple chloride bridge. Thus, the structure can be considered to be composed of face sharing octahedra. The P-Ru-P and P-Ru-Cl bond angles involving a phosphorus are normal and the Ru-Cl-Ru angles are near the mean distance of $82(3)^{\circ}$ of those of the 210 compounds in the CCDB that contain a $\mathrm{Ru}(\mu-\mathrm{Cl})_{3} \mathrm{Ru}$ unit $[15,16]$. In the only similar nitrile complex, $(\mathrm{L})_{2}(\mathrm{Cl}) \mathrm{Ru}(\mu-\mathrm{Cl})_{3} \mathrm{Ru}(\mathrm{NCMe})(\mathrm{L})_{2} \mathrm{~L}=$ Diphenyl-2-indolylphosphine, the NMR spectrum consists of "a number of poorly resolved signals" that was interpreted to indicate that the compound converts to a number of species in solution [8]. Clearly $\left(\mathrm{Ph}_{3} \mathrm{P}\right)_{2}(\mathrm{Cl}) \mathrm{Ru}(-\mu-$ $\mathrm{Cl})_{3} \mathrm{Ru}(\mathrm{NCPh})\left(\mathrm{PPh}_{3}\right)_{2}$ does not exhibit similar behavior.

\subsection{Redetermination of the X-Ray Crystal Structure of $\left[\mathrm{Ph}_{3} \mathrm{PMe}\right]\left[\mathrm{RuCl}_{4}\left(\mathrm{PPh}_{3}\right)_{2}\right]$.}

$\mathrm{RuCl}_{2}\left(\mathrm{PPh}_{3}\right)_{3}$ was prepared by the reaction of $\mathrm{RuCl}_{3} 3 \mathrm{H}_{2} \mathrm{O}$ with excess $\mathrm{PPh}_{3}$ in refluxing methanol. Following filtration to isolate the precipitate of $\mathrm{RuCl}_{2}\left(\mathrm{PPh}_{3}\right)_{3}$, orange crystals occasionally grew from the supernatant. A low temperature X-ray crystal structure determination identifies this side product to be the previously reported $\left[\mathrm{Ph}_{3} \mathrm{PMe}\right]\left[\mathrm{RuCl}_{4}\left(\mathrm{PPh}_{3}\right)_{2}\right]$ (Fig. 3) which is included herein for improved precision [18]. Although, the mechanism for formation has not been studied either by Polam and Porter or by us, a simple nucleophilic substitution reaction by triphenylphosphine on methanol to form the methyltriphenylphosphonium ion accompanied by 
association of two triphenylphosphines and a chloride to form the tetrachlorobis(triphenylphosphine)ruthenium(III) anion would be logical.

$$
\begin{aligned}
& \mathrm{PPh}_{3}+\mathrm{MeOH} \longrightarrow \mathrm{MePPh}_{3}^{+}+\mathrm{OH}^{-} \\
& \mathrm{RuCl}_{3}+\mathrm{Cl}^{-}+2 \mathrm{PPh}_{3} \longrightarrow \mathrm{RuCl}_{4}\left(\mathrm{PPh}_{3}\right)_{2}^{-} \\
& \mathrm{MePPh}_{3}^{+}+\mathrm{RuCl}_{4}\left(\mathrm{PPh}_{3}\right)_{2}^{-} \rightarrow\left[\mathrm{MePPh}_{3}\right]\left[\mathrm{RuCl}_{4}\left(\mathrm{PPh}_{3}\right)_{2}\right]
\end{aligned}
$$

We have revisited triphenylphosphine ruthenium nitrile chemistry and supplied crystallographic evidence consistent with and in support of the earlier spectroscopy. In doing so, we have extended the investigation to reactions involving excess $\mathrm{RuCl}_{2}\left(\mathrm{PPh}_{3}\right)_{3}$ where a solution stable triphenylphosphine diruthenium nitrile complex forms.

Acknowledgments The material is based on work supported by the National Science Foundation under CHE-1062629 and CRIF 1048367, and by the Research Corporation Departmental Science Development Award 7957.

\section{References}

[1] V. Y. Kukushkin, A. J. L. Pombeiro Inorganica Chimica Acta 358 (2005) 1-21.

[2] J. L. Wallick, C. G. Riordan, G. P. A. Yap Acta Crystallogr. C70 (2014) 640-643.

[3] CSD 5.36 Nov 2014: H. Allen Acta Crystallogr. B58 (2002) 380-388.

[4] A. M. Al-Far, L. M. Slaughter Acta Crystallogr., Sect. E: Struct. Rep. Online E64 (2008) m184.

[5] H. Katayama, F. Ozawa Organometallics 17 (1998) 5190-5196.

[6] J. D. Gilbert, G. Wilkinson J. Chem. Soc. (A) (1969) 1749-1752.

[7] S. O. Owallude, E. O. Odebunmi, U. B. Eke, A. L. Rheingold, N. Opembe, S. Suib J. Organomet.Chem. 739 (2013) 21-25. 
[8] Y. Kuo, M. F. Haddow, A. L. Jamieson, G. R. Owen Transition Met. Chem. 38 (2013) 641648.

[9] P. S. Hallman, T. A. Stephenson, G. Wilkinson Inorg. Synth. 12 (1970) 237-240.

[10] K. Marat SpinWorks 4.0.3.0, Univ. of Manitoba (2014.) .

[11] Apex2 Software Suite, Madison, WI (2005) .

[12] G. M. Sheldrick Acta Cryst. A64 (2008) 112-122.

[13] I. A. Guzzei J. Appl. Crystallogr. 47 (2014) 806-809.

[14] C. F. Macrae, I. J. Bruno, J. A. Chisholm, P. R. Edgington, P. McCabe, E. Pidcock, L. Rodriguez-Monge, R. Taylor, J. van de Streek, J. Wood J. Appl. Crystallogr. 41 (2008) 466-470.

[15] I. J. Bruno, J. C. Cole, M. Kessler, J. Luo, W. D. S. Motherwell, L. H. Purkis, B. R. Smith, R. Taylor, R. I. Cooper, S. E. Harris, A. G. Orpen J. Chem. Inf. Comput. Sci. 44 (2004) 21332144.

[16] I. J. Bruno, J. C. Cole, P. R. Edgington, M. Kessler, C. F. Macrae, P. McCabe, J. Pearson, R. Taylor Acta Cryst. B58 (2002) 389-397.

[17] D. E. Fogg, B. R. James Inorg. Chem. 36 (1997) 1961-1966.

[18] J. R. Polam, L. C. Porter J. Coord. Chem. 28 (1993) 297-304. 


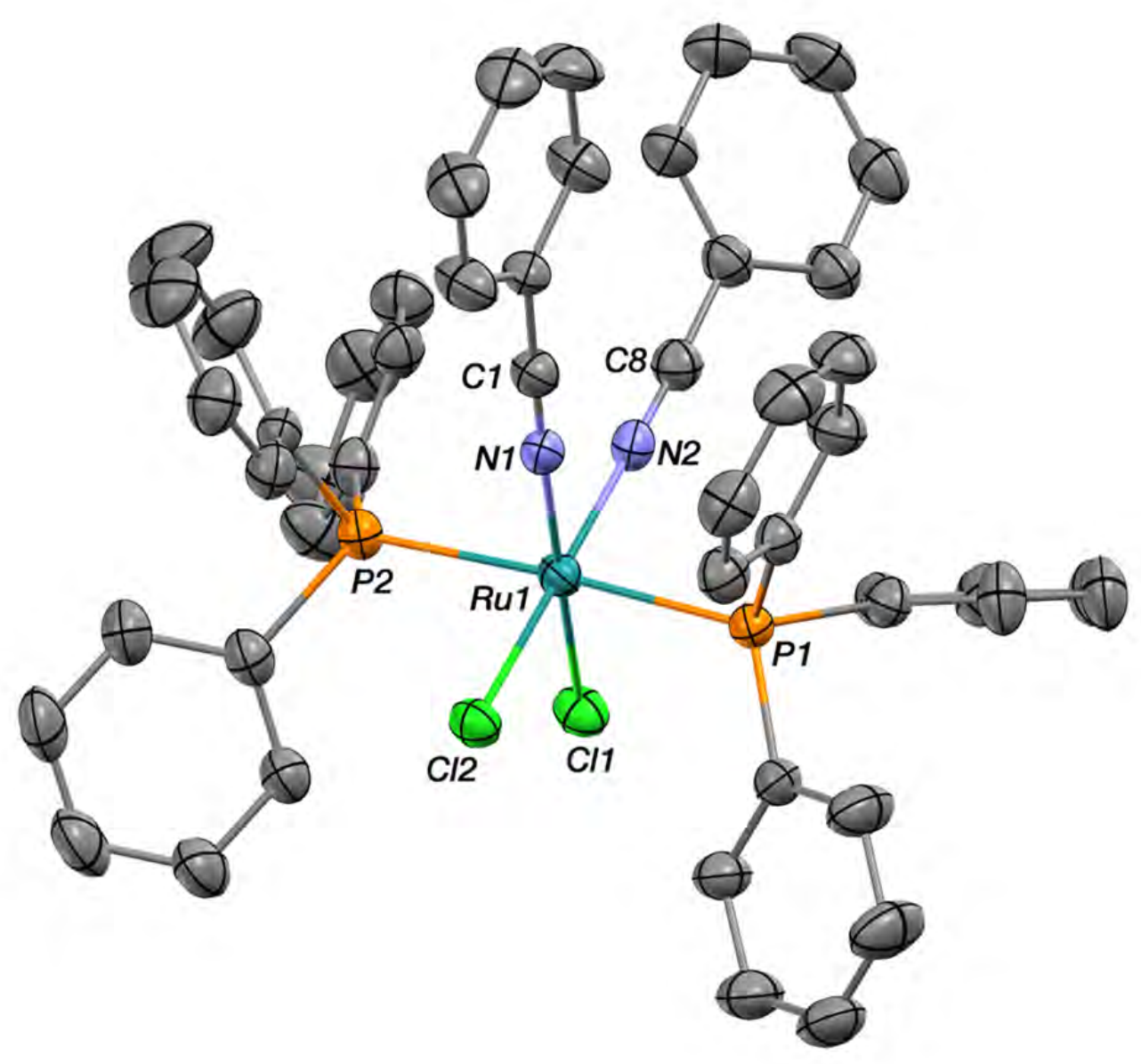

Figure 1. Molecular diagram of cis- $\mathrm{RuCl}_{2}\left(\mathrm{PPh}_{3}\right)_{2}(\mathrm{NCPh})_{2}$ with $30 \%$ probability ellipsoids. Hatoms and solvent molecules omitted for clarity. 


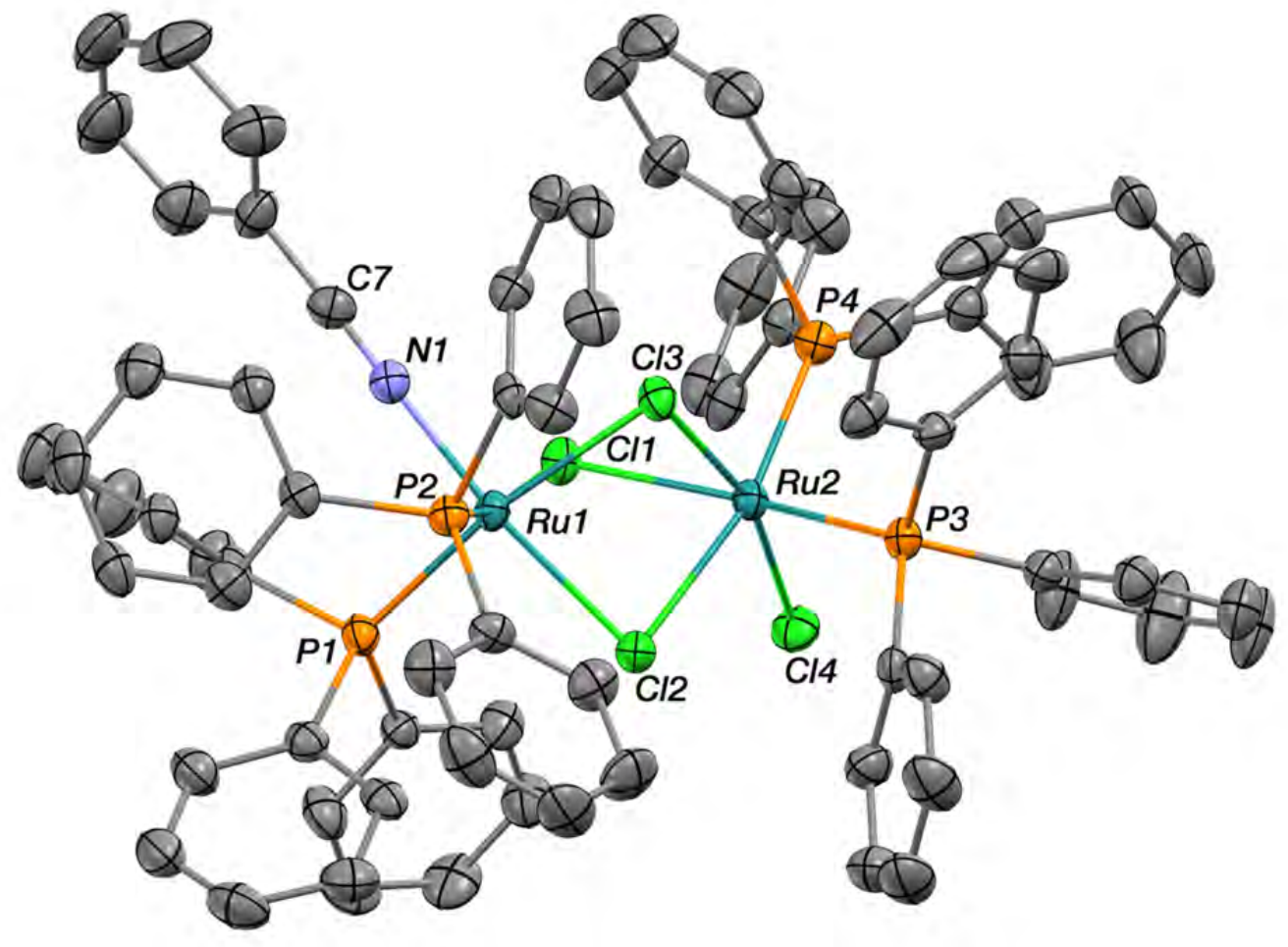

Figure 2. Molecular diagram of $\left(\mathrm{Ph}_{3} \mathrm{P}\right)_{2}(\mathrm{Cl}) \mathrm{Ru}(-\mu-\mathrm{Cl})_{3} \mathrm{Ru}(\mathrm{NCPh})\left(\mathrm{PPh}_{3}\right)_{2}$ with $30 \%$ probability ellipsoids. H-atoms and solvent molecules omitted for clarity. 


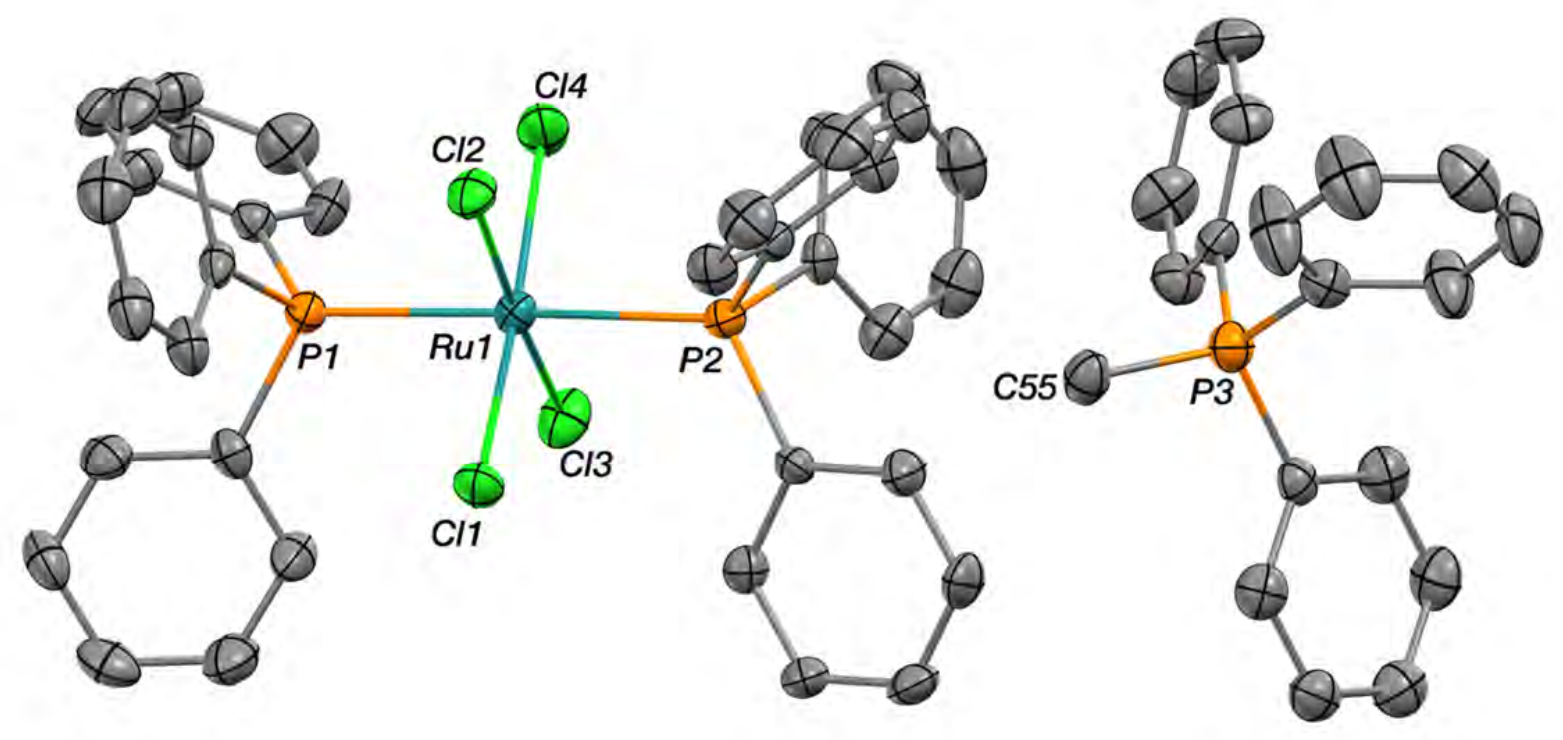

Figure 3. Molecular diagram of $\left[\mathrm{Ph}_{3} \mathrm{PMe}\right]\left[\mathrm{RuCl}_{4}\left(\mathrm{PPh}_{3}\right)_{2}\right]$ with $30 \%$ probability ellipsoids. $\mathrm{H}-$ atoms omitted for clarity. 
Table 1. Crystallographic data and structure refinement details

Compound
Empirical formula
Formula weight
Color, crystal shape
Crystal size $\left(\mathrm{mm}^{3}\right)$
$T(\mathrm{~K})$
Wavelength $(\AA)$
Crystal system
Space group
Unit cell dimensions
$a(\AA)$
$b(\AA)$
$c(\AA)$
$\alpha\left(^{\circ}\right)$
$\beta\left(^{\circ}\right)$
$\gamma\left({ }^{\circ}\right)$
$V\left(\AA^{3}\right)$
$Z$
$D_{\text {calc }}\left(\mathrm{g} / \mathrm{cm}^{3}\right)$
$\mu($ mm
$\theta$ range for data collection $\left({ }^{\circ}\right)$
Reflections collected
Independent reflections, $R_{\text {int }}$
Completeness $(\%)$ to $\theta=25^{\circ}$
Absorption correction
Max. and min. transmission
Refinement method
Data / restraints / parameters
Absolute structure parameter
Goodness-of-fit on $F^{2}$
Final $R_{1} / w R_{2}$ indices $[\mathrm{I}>2 \sigma(\mathrm{I})]$

$\mathrm{RuCl}_{2}\left(\mathrm{PPh}_{3}\right)_{2}(\mathrm{NCPh})_{2}$
$\mathrm{C}_{64} \mathrm{H}_{56} \mathrm{Cl}_{2} \mathrm{~N}_{2} \mathrm{P}_{2} \mathrm{Ru}$
1087.02
yellow, plate
0.470 x 0.319 x 0.126
$200(2)$
0.71073
triclinic
$P-1$
$11.729(3)$
$12.888(3)$
$19.563(5)$
$8.671(4)$
$96.778(4)$
$108.855(4)$
$2722.2(12)$
2
1.326
0.487
1.70 - 27.68
34939
$12492,0.0601$
100.0
Semi-empirical from equivalents
0.9412 and 0.8035
Full-matrix least-squares on $\mathrm{F}^{2}$
12492 / 248 / 636
$\mathrm{~N} / \mathrm{A}$
1.035
$0.0572,0.1125$

$\begin{array}{ll}\mathrm{Ru}_{2} \mathrm{Cl}_{4}\left(\mathrm{PPh}_{3}\right)_{4}(\mathrm{NCPh}) & {\left[\mathrm{CH}_{3} \mathrm{PPh}_{3}\right]\left[\mathrm{RuCl}_{4}\left(\mathrm{PPh}_{3}\right)_{2}\right]} \\ \mathrm{C}_{85} \mathrm{H}_{77} \mathrm{Cl}_{4} \mathrm{NO}_{2} \mathrm{P}_{4} \mathrm{Ru}_{2} & \mathrm{C}_{55} \mathrm{H}_{48} \mathrm{Cl}_{4} \mathrm{P}_{3} \mathrm{Ru} \\ 1612.29 & 1044.71 \\ \text { orange, needle } & \text { orange, block } \\ 0.265 \times 0.126 \times 0.090 & 0.268 \times 0.167 \times 0.141 \\ 200(2) & 200(2) \\ 0.71073 & 0.71073 \\ \text { monoclinic } & \text { orthorhombic } \\ P 2{ }_{1} / c & P 2_{1} 2_{1} 2_{1} \\ & \\ 13.9563(12) & 10.725(3) \\ 22.510(2) & 20.663(6) \\ 24.092(2) & 21.569(6) \\ 90 & 90 \\ 93.412(2) & 90 \\ 90 & 90 \\ 7555.3(12) & 4780(2) \\ 4 & 4 \\ 1.417 & 1.452 \\ 0.675 & 0.690 \\ 1.694 \text { - 27.543 } & 1.888-27.482 \\ 83595 & 31831 \\ 17366,0.1316 & 10930,0.1163 \\ 100.0 & 100.0 \\ \text { Semi-empirical from equivalents } & \text { Semi-empirical from equivalents } \\ 0.7456 \text { and } 0.6677 & 0.7456 \text { and } 0.6658 \\ \text { Full-matrix least-squares on } \mathrm{F}^{2} & \text { Full-matrix least-squares on } \mathrm{F}^{\wedge} 2 \\ 17366 / 72 / 875 & 10930 / 0 / 569 \\ \mathrm{~N} / \mathrm{A} & 0.00(4) \\ 0.990 & 0.994 \\ 0.0548,0.1105 & 0.0613,0.0902 \\ & \end{array}$


Table 2. Selected bond lengths $(\AA)$ and angles $\left(^{\circ}\right)$ for $\mathrm{RuCl}_{2}\left(\mathrm{PPh}_{3}\right)_{2}(\mathrm{NCPh})_{2}$.

\begin{tabular}{lc}
\hline Ru1-N1 & $1.982(3)$ \\
Ru1-N2 & $2.000(3)$ \\
Ru1-P1 & $2.3892(12)$ \\
Ru1-P2 & $2.3957(12)$ \\
Ru1-C12 & $2.4172(11)$ \\
Ru1-Cl1 & $2.4305(11)$ \\
N1-C1 & $1.143(5)$ \\
N2-C8 & $1.145(5)$ \\
& \\
N1-Ru1-N2 & $86.13(12)$ \\
N1-Ru1-P1 & $88.71(9)$ \\
N2-Ru1-P1 & $91.18(9)$ \\
N1-Ru1-P2 & $90.30(9)$ \\
N2-Ru1-P2 & $93.69(9)$ \\
P1-Ru1-P2 & $174.96(4)$ \\
N1-Ru1-Cl2 & $89.47(9)$ \\
N2-Ru1-C12 & $175.31(9)$ \\
P1-Ru1-C12 & $87.08(3)$ \\
P2-Ru1-C12 & $87.97(3)$ \\
N1-Ru1-Cl1 & $174.57(9)$ \\
N2-Ru1-Cl1 & $88.92(9)$ \\
P1-Ru1-Cl1 & $93.65(4)$ \\
P2-Ru1-Cl1 & $87.76(4)$ \\
C12-Ru1-Cl1 & $95.54(4)$ \\
& \\
C1-N1-Ru1 & $173.9(3)$ \\
C8-N2-Ru1 & $173.4(3)$ \\
\end{tabular}


Table 3. Selected bond lengths $(\AA)$ and angles $\left(^{\circ}\right)$ for $\mathrm{Ru}_{2} \mathrm{Cl}_{4}\left(\mathrm{PPh}_{3}\right)_{4}(\mathrm{NCPh})$.

\begin{tabular}{|c|c|}
\hline Ru1-N1 & $1.982(4)$ \\
\hline Ru1-P1 & $2.3103(13)$ \\
\hline Ru1-P2 & $2.3278(13)$ \\
\hline $\mathrm{Ru} 1-\mathrm{Cl} 2$ & $2.4088(12)$ \\
\hline $\mathrm{Ru} 1-\mathrm{Cl} 3$ & $2.4441(12)$ \\
\hline Ru1-Cl1 & $2.4702(12)$ \\
\hline Ru2-P4 & $2.2784(14)$ \\
\hline Ru2-P3 & $2.2796(13)$ \\
\hline $\mathrm{Ru} 2-\mathrm{Cl} 3$ & $2.3886(12)$ \\
\hline Ru2-Cl4 & $2.4050(12)$ \\
\hline $\mathrm{Ru} 2-\mathrm{Cl} 2$ & $2.5090(12)$ \\
\hline $\mathrm{Ru} 2-\mathrm{Cl1}$ & $2.5424(13)$ \\
\hline N1-C7 & $1.137(6)$ \\
\hline N1-Ru1-P1 & $92.67(12)$ \\
\hline N1-Ru1-P2 & $88.09(12)$ \\
\hline P1-Ru1-P2 & $99.76(5)$ \\
\hline N1-Ru1-C12 & $169.04(12)$ \\
\hline P1-Ru1-C12 & $90.87(4)$ \\
\hline P2-Ru1-Cl2 & $101.53(5)$ \\
\hline N1-Ru1-Cl3 & $95.25(12)$ \\
\hline P1-Ru1-C13 & $168.43(4)$ \\
\hline P2-Ru1-C13 & $88.94(4)$ \\
\hline Cl2-Ru1-Cl3 & $79.85(4)$ \\
\hline N1-Ru1-Cl1 & $86.31(12)$ \\
\hline P1-Ru1-C11 & $93.69(5)$ \\
\hline P2-Ru1-Cl1 & $165.65(5)$ \\
\hline Cl2-Ru1-Cl1 & $83.11(4)$ \\
\hline Cl3-Ru1-Cl1 & $78.44(4)$ \\
\hline P4-Ru2-P3 & $98.21(5)$ \\
\hline P4-Ru2-Cl3 & $93.67(5)$ \\
\hline P3-Ru2-Cl3 & $94.12(5)$ \\
\hline P4-Ru2-Cl4 & $97.29(5)$ \\
\hline P3-Ru2-Cl4 & $95.65(5)$ \\
\hline Cl3-Ru2-Cl4 & $164.12(4)$ \\
\hline P4-Ru2-Cl2 & $166.90(5)$ \\
\hline P3-Ru2-Cl2 & $93.14(4)$ \\
\hline $\mathrm{Cl} 3-\mathrm{Ru} 2-\mathrm{Cl} 2$ & $78.94(4)$ \\
\hline $\mathrm{Cl} 4-\mathrm{Ru} 2-\mathrm{Cl} 2$ & $88.04(4)$ \\
\hline P4-Ru2-Cl1 & $88.24(5)$ \\
\hline P3-Ru2-Cl1 & $170.22(5)$ \\
\hline Cl3-Ru2-Cl1 & $78.06(4)$ \\
\hline Cl4-Ru2-Cl1 & $90.79(4)$ \\
\hline Cl2-Ru2-Cl1 & $79.70(4)$ \\
\hline Ru1-Cl1-Ru2 & $82.65(4)$ \\
\hline $\mathrm{Ru} 1-\mathrm{Cl} 2-\mathrm{Ru} 2$ & $84.59(4)$ \\
\hline $\mathrm{Ru} 2-\mathrm{Cl} 3-\mathrm{Ru} 1$ & $86.46(4)$ \\
\hline C7-N1-Ru1 & $177.6(4)$ \\
\hline
\end{tabular}


Table 4. Selected bond lengths $(\AA)$ and angles $\left(^{\circ}\right)$ for $\left[\mathrm{CH}_{3} \mathrm{PPh}_{3}\right]\left[\mathrm{RuCl}_{4}\left(\mathrm{PPh}_{3}\right)_{2}\right]$.

$\begin{array}{lr}\text { Ru1-Cl1 } & 2.372 \\ \text { Ru1-Cl2 } & 2.364 \\ \text { Ru1-Cl3 } & 2.375 \\ \text { Ru1-Cl4 } & 2.361 \\ \text { Ru1-P1 } & 2.413 \\ \text { Ru1-P2 } & 2.411 \\ \text { P3-C55 } & 1.798 \\ & \\ \text { Cl4-Ru1-C12 } & \\ \text { Cl4-Ru1-C11 } & 85.34(8) \\ \text { Cl2-Ru1-C11 } & 174.25(9) \\ \text { Cl4-Ru1-C13 } & 89.05(8) \\ \text { Cl2-Ru1-Cl3 } & 90.27(9) \\ \text { C11-Ru1-C13 } & 175.54(9) \\ \text { Cl4-Ru1-P2 } & 95.35(8) \\ \text { C12-Ru1-P2 } & 90.20(8) \\ \text { Cl1-Ru1-P2 } & 92.17(8) \\ \text { Cl3-Ru1-P2 } & 91.29(8) \\ \text { Cl4-Ru1-P1 } & 86.99(7) \\ \text { Cl2-Ru1-P1 } & 90.96(8) \\ \text { Cl1-Ru1-P1 } & 88.78(8) \\ \text { Cl3-Ru1-P1 } & 87.63(9) \\ \text { P2-Ru1-P1 } & 92.15(8) \\ & 178.56(9)\end{array}$




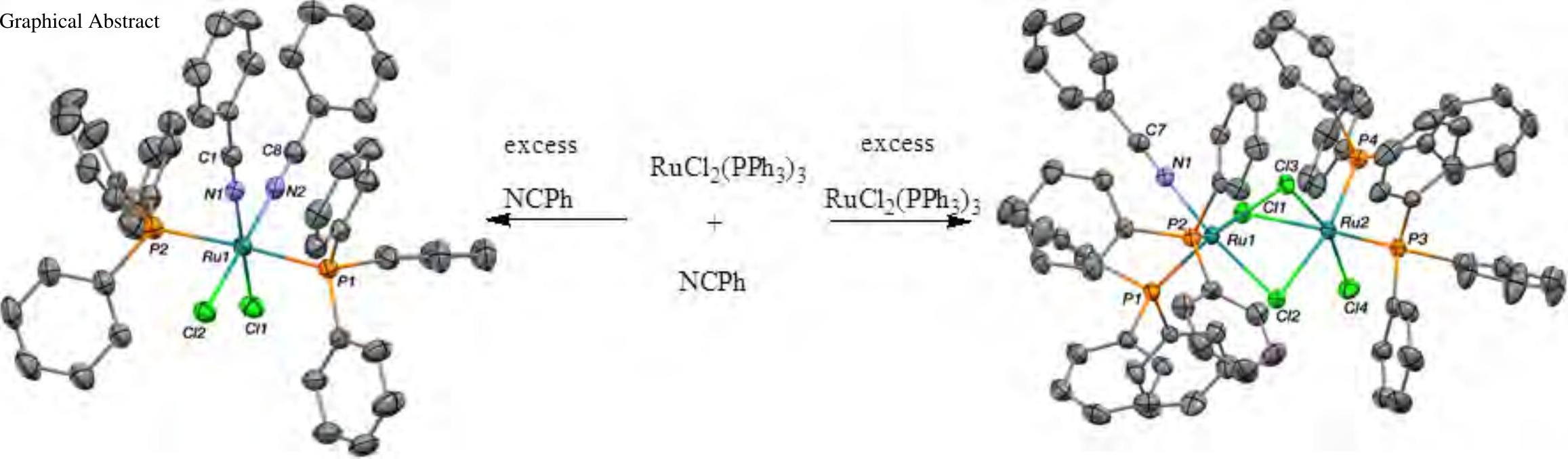

